\title{
Consistency in bird community assembly over medium-term along rural-urban gradients in Argentina
}

Lucas M. Leveau

\begin{abstract}
Background: The analysis of bird community assembly rules is fundamental to understand which mechanisms determine the composition of bird species in urban areas. However, the long-term variation of community assembly rules has not been analyzed yet. The objectives of this study are (1) to analyze the variation of community assembly rules along rural-urban gradients of three cities in central Argentina and (2) to compare the patterns of community assembly between two periods separated by 6 years. Bird surveys were performed along transects in urban, suburban, and rural habitats during 2011 and 2017. Departures from null models that took into account differences in species richness (standardized effect size, SES) were calculated for functional and phylogenetic diversities.

Results: A total of 57 species were recorded. Bird species richness was higher in suburban than in urban and rural habitats. SES of functional diversity increased over the years and was significantly lower in urban habitats than in rural habitats, showing a pattern of functional clustering in the most urbanized areas and functional randomness in rural ones. Phylogenetic diversity was higher in both suburban and urban habitats than rural ones, and the phylogenetic clustering in rural bird assemblages changed to randomness in suburban and urban habitats.

Conclusions: Bird communities in urban habitats were phylogenetically random and functionally clustered, evidencing environmental filtering by urbanization. In contrast, bird communities in rural areas tended to be phylogenetically clustered, evidencing that certain clades are adapted to rural areas. The processes structuring bird communities along rural-urban gradients were consistent between the 2 years compared.
\end{abstract}

Keywords: Birds, Interannual, Latin America, Neotropics, Urbanization

\section{Introduction}

Urban areas are expanding continuously, causing declines of bird diversity mainly through habitat loss and fragmentation, pollution, and altered resource flows (Grimm et al. 2008; Aronson et al. 2014; Shanahan et al. 2014; Beninde et al. 2015). This diversity decline is reflected in the taxonomic, functional, and phylogenetic diversity (Devictor et al. 2010; Morelli et al. 2017; Liu et al. 2019; Leveau and Leveau 2020). Taxonomic

Correspondence: lucasleveau@yahoo.com.ar

Departamento de Ecología, Genética y Evolución, Facultad de Ciencias

Exactas y Naturales, Universidad de Buenos Aires-IEGEBA (CONICET-UBA),

Ciudad Universitaria, Pab 2, Piso 4, 1426 Buenos Aires, Argentina diversity is characterized by the number of species in a site (Cadotte and Tucker 2018). Functional diversity reflects the range and variety of resources that species obtain (Díaz and Cabido 2001), whereas phylogenetic diversity is related to the phylogenetic relationships among species (Jetz et al. 2014). Birds in urban areas are mainly habitat and food generalists, so urban bird communities show reduced functional diversity (Schütz and Schulze 2015; Oliveira Hagen et al. 2017; Palacio 2020). On the other hand, a reduced phylogenetic diversity in urban areas has been found due to generalist species being closely related to each other (Ibáñez-Âlamo et al., 2017; Sol et al. 2017; La Sorte et al. 2018).

\section{Springer Open}

(c) The Author(s). 2021 Open Access This article is licensed under a Creative Commons Attribution 4.0 International License, which permits use, sharing, adaptation, distribution and reproduction in any medium or format, as long as you give appropriate credit to the original author(s) and the source, provide a link to the Creative Commons licence, and indicate if changes were made. The images or other third party material in this article are included in the article's Creative Commons licence, unless indicated otherwise in a credit line to the material. If material is not included in the article's Creative Commons licence and your intended use is not permitted by statutory regulation or exceeds the permitted use, you will need to obtain permission directly from the copyright holder. To view a copy of this licence, visit http://creativecommons.org/licenses/by/4.0/. 
The analysis of community assembly rules is fundamental to understand urban bird communities because it allows predicting how species from the regional pool are assembled in urban areas (Magura et al. 2018). Two aspects during the last decade have allowed to analyze community assembly rules along urbanization gradients (Moreno-Contreras et al. 2019, Weideman et al., 2020): (1) the availability of information regarding phylogenetic relationships among coexisting bird species and their functional characteristics (Jetz et al. 2014, Wilman et al. 2014) and (2) the possibility to compare the observed phylogenetic and functional diversity against null models that take into account differences in species richness (Swenson 2014).

The contrast of observed functional diversity values with those obtained with null models allows suggesting departures from random, or stochastic, processes to deterministic processes molding bird communities, such as environmental filtering or competition (Petchey et al. 2007). Observed functional diversity lower than expected by chance, hereafter functional clustering, suggests a mechanism of environmental filtering from the regional pool, allowing the coexistence of species with similar traits (Petchey et al. 2007). A higher observed diversity than expected by chance, hereafter functional overdispersion, suggests species competition because coexisting species are functionally more different than expected, thus avoiding competition for resources (Petchey et al. 2007). On the other hand, the phylogenetic diversity departures from null models show patterns of phylogenetic clustering or overdispersion (Webb et al. 2002), where coexisting species are closely related or more distant than expected, respectively.

The integration of functional and phylogenetic departures from null models results in four scenarios (Webb et al. 2002; Emerson and Gillespie 2008): (1) functional and phylogenetic clustering of communities, which suggests that similar traits among coexisting species are phylogenetically conserved; (2) functional clustering with phylogenetic overdispersion or randomness of communities, which suggests that similar traits of coexisting species resulted from convergent evolution; (3) functional overdispersion with phylogenetic clustering or randomness of communities, which suggests that different traits resulted from convergent evolution among coexisting species; and (4) functional and phylogenetic overdispersion, which suggest that different traits among coexisting species resulted from conserved traits.

Analyses of bird community assembly rules along urbanization gradients are scarce and have shown that urban bird communities are phylogenetically and functionally random (Weideman et al., 2020), or functionally clustered with phylogenetic randomness, suggesting a mechanism of environmental filtering
(Moreno-Contreras et al. 2019). On the other hand, the temporal variation of community assembly rules along urbanization gradients has seldom been assessed.

Interannual variations in climatic conditions that affect resource availability and habitat structure for birds and species colonization or extinctions can affect bird species richness and community assembly patterns (Li et al. 2015, Rota et al. 2017, Weyland et al. 2019). However, bird communities in urban areas are expected to be more stable than in rural areas (Suhonen et al. 2009, Leveau et al. 2015), presumably because of the less variable habitat structure and food availability in urban areas (Shochat et al. 2006, Leveau 2018). This is underlined by the fact that the effects of hurricanes, tornados, and fire on vegetation structure are reduced or suppressed in urban areas (Argañaraz et al. 2015; Kingfield and De Beurs 2017; Pickens et al., 2017). Activities such as irrigation, maintaining vegetation, or using fertilizers and pesticides may buffer the interannual variation of primary productivity in urban areas (Shochat et al. 2004; Leong and Roderick 2015) and the interannual variation of habitat structure in suburban ones (Guthrie 1974, Lepczyk et al. 2004).

The aims of this study were (1) to analyze the variation of community assembly rules along rural-urban gradients of three cities in central Argentina and (2) to compare the patterns of community assembly between two periods separated by 6 years. A functional clustering with phylogenetic randomness was expected in bird communities of urban areas of both years. However, long-term changes in community assembly are expected in rural areas as a response to climatic and habitat structure changes, species extinction, and colonization.

\section{Materials and methods}

\section{Study area}

The study was carried out in three cities of the Pampas Region, central Argentina (Fig. 1): Mar del Plata (38 00' S, 57 33'W; 38 m.a.s.l.; 615,350 inhabitants), Balcarce (37 $50^{\prime} \mathrm{S}, 58^{\circ} 15^{\prime} \mathrm{W} ; 112$ m.a.s.l.; 38,823 inhabitants), and Miramar ( $38^{\circ} 16^{\prime} \mathrm{S}, 57^{\circ} 50^{\prime} \mathrm{W}$; 17 m.a.s.l.; 29,629 inhabitants, 2010 National census). The three cities were in the same region, separated by a maximum distance of $59 \mathrm{~km}$; therefore, the influence of latitude or climate was negligible. The landscape surrounding the cities is composed mainly by grazing land, cropland, and exotic tree plantations. The climate is temperate, with mean annual precipitation of $923.6 \mathrm{~mm}$ and mean annual temperature of $14{ }^{\circ} \mathrm{C}$ (data from the National Meteorological Service, www.smn.org.ar).

\section{Bird surveys}

Three habitat types were selected for bird surveys: (1) rural, composed of crops and pastures; (2) suburban, 


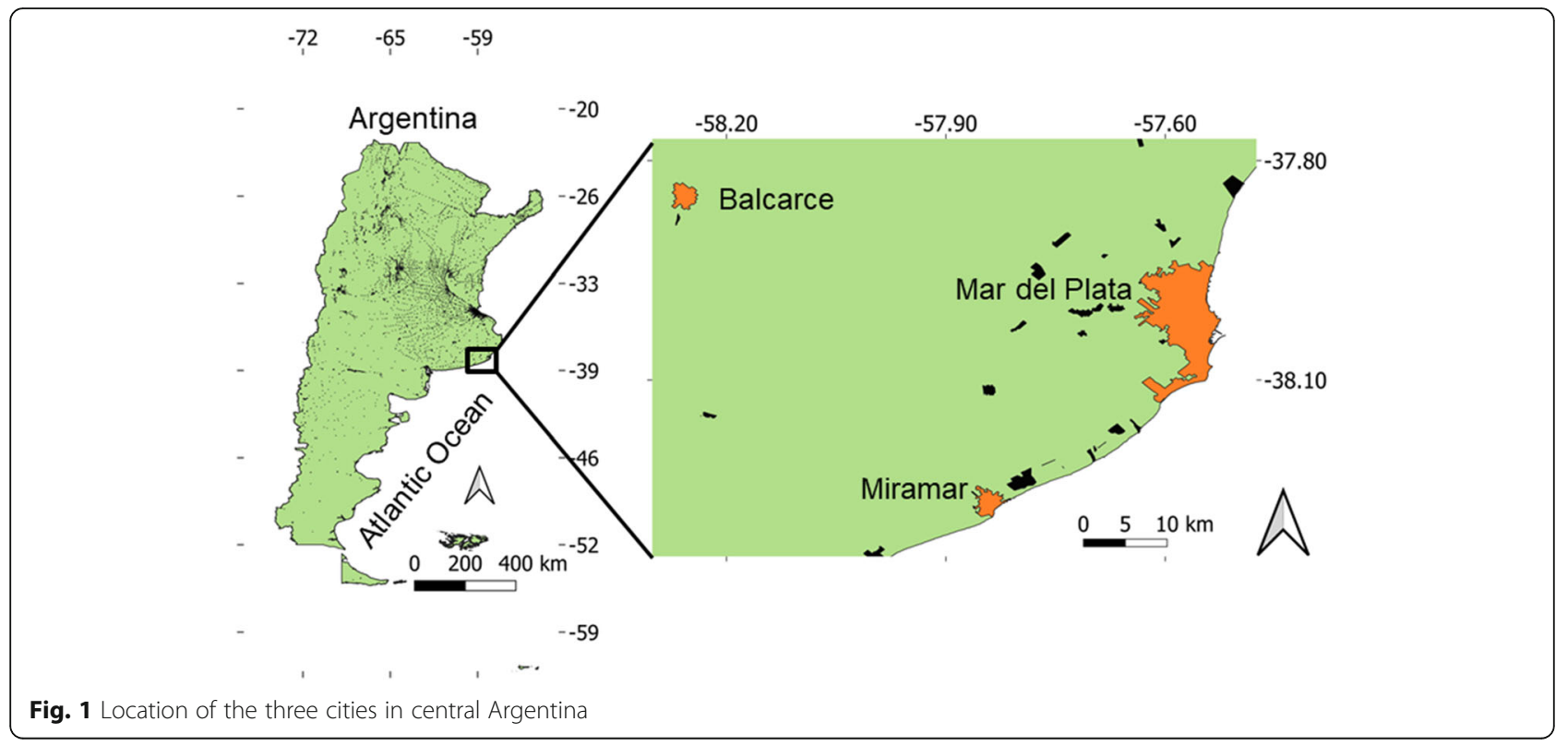

composed of detached houses with yards; and (3) urban dominated by impervious surfaces (see Leveau, 2019 for details). Five $100 \times 50$-m transects separated by at least $200 \mathrm{~m}$ were placed in each habitat (see also Rajashekara and Venkatesha 2015). Transects were visited once during each December 2011 and 2017. Surveys were carried out in the first $4 \mathrm{~h}$ after dawn on days without rain or strong winds, and all birds seen or heard were counted, except those flying over the top of buildings or trees, or below that height but showing no feeding activity.

\section{Sample coverage}

Because transects visited once each year may not be enough to detect most of the species present, sampling completeness was estimated for each transect each year. The sample coverage was estimated with the function iNEXT of the iNEXT package (Hsieh et al. 2016) and is the proportion of the total number of individuals that belong to the species detected in the transect. The sample coverage was used as an explanatory variable in models.

\section{Environmental and climatic changes between periods}

In Mar del Plata, 2017 had a higher annual mean temperature than $2011\left(15.17{ }^{\circ} \mathrm{C}\right.$ versus $13.92{ }^{\circ} \mathrm{C}$, respectively), and the annual precipitation was also higher (1405.8 $\mathrm{mm}$ in 2017 vs. $1103 \mathrm{~mm}$ in 2011). Moreover, whereas the habitat structure of urban and suburban habitats remained stable, most of the transects in the rural habitat had a replacement of crops by abandoned fields.

\section{Taxonomic, functional, and phylogenetic diversity}

The taxonomic alpha diversity of each transect during each year was determined as the bird species richness, which was the total number of species in each visit. The functional alpha diversity for each transect during each year was measured using a matrix of bird traits as columns, and bird species as rows was constructed. Functional traits were related to the way species obtain resources and were obtained from the EltonTraits 1.0 database (Wilman et al. 2014), which provides information about diet, foraging strata, and body mass (g) (see Supplementary Table S1). The database contains information of percent usage of each diet and foraging strata category. Additionally, information about clutch size and residency status was obtained from the Handbook of the Birds of the World (HBW) online (https://www.hbw. $\mathrm{com} /$ ). With the matrix of species and traits, we calculated the species dissimilarities using the Gower distance because our data traits had continuous as well as binary data, using the function gowdis of the $F D$ package in $\mathrm{R}$ (Laliberté et al. 2014, R Core Team 2017). Because functional diversity is generally positively related to species richness (Petchey and Gaston 2002, Weideman et al. 2020), the function ses.mpd of the package picante was used (Kembel et al. 2010). This function calculates the standardized effect size (SES) of mean pairwise distances in communities (hereafter, SES of functional diversity), taking into account differences in species richness with the null model "richness" using 999 randomizations. SES of functional diversity was based on species presence/absence data.

The phylogenetic alpha diversity was measured for each transect during each year, using a dated phylogeny of all species in this study from the BirdTree database 
(https://www.birdtree.org; Jetz et al. 2014). A total of 1000 phylogenies were downloaded from the Ericsson backbone phylogeny (Ericsson et al. 2006). A 50\% majority-rule consensus tree was constructed using the software TreeAnnotator (Rambaut and Drummond 2002-2015). The tree was used in $\mathrm{R}$ with the functions read.nexus and as.phylo of the ape package (Paradis et al. 2004). This function ses.mpd was used to calculate the standardized effect size (SES) of mean pairwise distances in communities (hereafter, SES of phylogenetic diversity), taking into account differences in species richness with the null model "richness" using 999 randomizations. SES of phylogenetic diversity was based on species presence/absence data.

\section{Statistical analysis}

The differences of alpha diversity in relation to sample coverage, habitats, years, and the interaction between habitat and years were analyzed through generalized linear mixed models (GLMM). Sample coverage was a continuous variable, whereas habitat and year were categorical variables. Therefore, the relationships between alpha diversity, habitat, and years were analyzed depending on a fixed value of sample coverage (James et al. 2013). Bird species richness variation was analyzed using a negative binomial distribution of errors due to overdispersion with the glmer.nb function of the lme4 package (Bates et al. 2018). SES of functional and phylogenetic diversity variations were analyzed using a Gaussian distribution of errors with the function lme of the nlme package (Pinheiro et al. 2013). A random structure with transects nested within city was used to control for spatial and temporal pseudoreplication. Models were constructed by backward elimination of non-significant variables $(P>0.05)$ from the full model using the anova function. Final models were contrasted against null models using a likelihood ratio test (LRT test) $(P<0.05)$. Differences of means between habitats were explored with Tukey tests using the function glht of the multcomp package (Hothorn et al. 2016). Multicollinearity was explored with the function vif of the car package (Fox et al. 2012), and no multicollinearity was detected between predictor variables. Plots were made with the plot_model function of the sjPlot package (Lüdecke et al. 2018).

\section{Results}

A total of 57 species were recorded (Table 1). The House Sparrow (Passer domesticus) and the Rock Dove (Columba livia) were common in urban habitats. The Picazuro Pigeon (Patagioenas picazuro), the Eared Dove (Zenaida auriculata), and the Red-bellied Thrush (Turdus rufiventris) were common in suburban habitats, whereas the Rufous-collared Sparrow (Zonotrichia capensis), the Grassland Yellow-finch (Sicalis luteola), and the Monk Parakeet (Myiopsitta monachus) were common in rural habitats. Most of the species were more common during 2017 (Table 1).

The mean sample coverage of transects was 0.80 , ranging from 0.18 to 1.00 . Therefore, there was a considerable heterogeneity in the sample coverage between transects. The sample coverage was included in the models explaining the relationship between the response variables and the habitat type and years.

Bird species richness varied between habitats and in relation to sample coverage (LRT $=43.32, P<0.001$; Table 2). Bird species richness was higher in suburban habitats than in urban and rural ones (Tukey tests, $P<$ 0.05 ) and decreased with increasing sample coverage, suggesting that transects with high species richness were undersampled (Fig. 2a, b).

SES of functional diversity varied in relation to habitats and years (LRT $=21.94, P<0.001$; Table 2). SES of functional diversity was significantly lower in urban habitats than in rural ones (Tukey test, $P<0.05$; Fig. 2c), showing a pattern of functional clustering in the most urbanized areas and functional randomness in rural habitats. Moreover, SES of functional diversity increased between the first and the second census, showing functional clustering in 2011 and functional randomness in 2017 (Fig. 2d).

SES of phylogenetic diversity varied between habitats and in relation to sample coverage (LRT $=10.39, P=$ 0.006; Table 2). SES of phylogenetic diversity was higher in urban and suburban than in rural habitats (Tukey tests, $P<0.05$; Table 2; Fig. 2e), showing phylogenetic randomness in urban and suburban habitats and a phylogenetic clustering in rural ones. Moreover, SES of phylogenetic diversity decreased with sample coverage, suggesting that transects with bird communities characterized by high phylogenetic diversity were undersampled (Fig. 2f).

\section{Discussion}

Although the mean sample coverage of transects was high, there was a variation among transects that was significantly related to bird species richness and phylogenetic diversity. Therefore, the results obtained must be interpreted with caution.

Community assembly rules varied along the gradients, suggesting environmental filtering and phylogenetic randomness in urban areas. Conversely, rural areas were associated with functional randomness and phylogenetic clustering. Moreover, although functional diversity changed between years, these changes were similar along rural-urban gradients, suggesting consistent community assembly rules. 
Table 1 Species frequencies (proportion of transects occupied) along the three rural-urban gradients during 2011 and 2017 in central Argentina

\begin{tabular}{|c|c|c|c|c|c|c|c|}
\hline \multirow[t]{2}{*}{ English name } & \multirow[t]{2}{*}{ Scientific name } & \multicolumn{3}{|l|}{2011} & \multicolumn{3}{|l|}{2017} \\
\hline & & Rural & Suburban & Urban & Rural & Suburban & Urban \\
\hline Red-winged Tinamou & Rhynchotus rufescens & - & - & - & 0.20 & - & - \\
\hline White-faced Ibis & Plegadis chihi & 0.07 & - & - & - & - & - \\
\hline Yellow-billed Teal & Anas flavirostris & - & - & - & 0.07 & - & - \\
\hline Long-winged Harrier & Circus buffoni & - & - & - & 0.07 & - & - \\
\hline Southern Lapwing & Vanellus chilensis & 0.20 & - & - & 0.13 & - & - \\
\hline Rock Dove & Columba livia & - & 0.20 & 0.73 & 0.07 & 0.27 & 0.87 \\
\hline Picazuro Pigeon & Patagioenas picazuro & 0.07 & 0.73 & 0.07 & - & 0.80 & 0.07 \\
\hline Spot-winged Pigeon & Patagioenas maculosa & 0.07 & 0.20 & 0.13 & - & 0.47 & 0.33 \\
\hline Eared Dove & Zenaida auriculata & 0.13 & 0.93 & 0.80 & 0.13 & 0.73 & 0.93 \\
\hline Picui Dove & Columbina picui & - & 0.07 & - & - & - & - \\
\hline Guira Cuckoo & Guira guira & 0.13 & 0.07 & - & 0.13 & - & - \\
\hline Burrowing Owl & Athene cunicularia & 0.07 & - & - & - & - & - \\
\hline Short-eared Owl & Asio flammeus & 0.07 & - & - & - & - & - \\
\hline Glittering-bellied Emerald & Chlorostilbon lucidus & - & - & - & - & 0.13 & - \\
\hline White-throated Hummingbird & Leucochloris albicollis & - & 0.07 & - & - & 0.20 & - \\
\hline Green-barred Woodpecker & Colaptes melanochloros & - & 0.13 & - & - & - & - \\
\hline Campo Flicker & Colaptes campestris & 0.07 & - & - & 0.07 & - & - \\
\hline Southern Crested Caracara & Caracara plancus & - & - & - & 0.07 & - & - \\
\hline Chimango Caracara & Phalcoboenus chimango & 0.07 & 0.13 & 0.07 & 0.13 & 0.27 & 0.27 \\
\hline American Kestrel & Falco sparverius & 0.07 & - & - & - & - & - \\
\hline Monk Parakeet & Myiopsitta monachus & 0.07 & - & - & 0.27 & 0.07 & - \\
\hline Rufous Hornero & Furnarius rufus & - & 0.40 & 0.07 & 0.07 & 0.73 & 0.20 \\
\hline Firewood-gatherer & Anumbius anumbi & 0.13 & - & - & 0.07 & - & - \\
\hline Small-billed Elaenia & Elaenia parvirostris & - & 0.40 & - & - & 0.27 & - \\
\hline White-crested Tyrannulet & Serpophaga subcristata & - & 0.20 & - & - & 0.20 & - \\
\hline Cattle Tyrant & Machetornis rixosus & - & 0.07 & - & - & - & - \\
\hline Great Kiskadee & Pitangus sulphuratus & - & 0.33 & 0.07 & 0.20 & 0.60 & 0.13 \\
\hline Tropical Kingbird & Tyrannus melancholicus & 0.13 & 0.27 & - & 0.13 & 0.27 & - \\
\hline Fork-tailed Flycatcher & Tyrannus savana & 0.27 & - & - & 0.33 & - & - \\
\hline Brown-chested Martin & Progne tapera & - & - & - & 0.07 & - & - \\
\hline Grey-breasted Martin & Progne chalybea & - & - & 0.07 & - & - & 0.20 \\
\hline Southern Martin & Progne elegans & - & - & 0.07 & - & - & 0.07 \\
\hline White-rumped Swallow & Tachycineta leucorrhoa & - & 0.13 & - & 0.27 & - & 0.07 \\
\hline Barn Swallow & Hirundo rustica & 0.13 & - & 0.07 & 0.47 & 0.53 & 0.40 \\
\hline House Wren & Troglodytes aedon & 0.07 & 0.40 & 0.13 & 0.27 & 0.47 & 0.07 \\
\hline Rufous-bellied Thrush & Turdus rufiventris & - & 0.53 & 0.13 & - & 0.60 & - \\
\hline Chalk-browed Mockingbird & Mimus saturninus & 0.20 & 0.40 & - & 0.20 & 0.33 & - \\
\hline Correndera Pipit & Anthus correndera & 0.27 & - & - & 0.20 & - & - \\
\hline Blue-and-yellow Tanager & Pipraeidea bonariensis & - & 0.07 & - & - & - & - \\
\hline Saffron Finch & Sicalis flaveola & - & 0.07 & - & 0.13 & 0.20 & 0.07 \\
\hline Grassland Yellow-finch & Sicalis luteola & 0.27 & - & - & 0.53 & - & - \\
\hline Great Pampa-finch & Embernagra platensis & 0.07 & - & - & - & - & - \\
\hline
\end{tabular}


Table 1 Species frequencies (proportion of transects occupied) along the three rural-urban gradients during 2011 and 2017 in central Argentina (Continued)

\begin{tabular}{|c|c|c|c|c|c|c|c|}
\hline \multirow[t]{2}{*}{ English name } & \multirow[t]{2}{*}{ Scientific name } & \multicolumn{3}{|l|}{2011} & \multicolumn{3}{|l|}{2017} \\
\hline & & Rural & Suburban & Urban & Rural & Suburban & Urban \\
\hline Double-collared Seedeater & Sporophila caerulescens & 0.27 & - & - & 0.20 & - & - \\
\hline Rufous-collared Sparrow & Zonotrichia capensis & 0.67 & 0.53 & 0.07 & 0.67 & 0.27 & - \\
\hline Tropical Parula & Setophaga pitiayumi & - & 0.07 & - & - & 0.07 & - \\
\hline Yellow-winged Blackbird & Agelasticus thilius & 0.07 & - & - & - & - & - \\
\hline Brown-and-yellow Marshbird & Pseudoleistes virescens & - & - & - & 0.07 & - & - \\
\hline Bay-winged Cowbird & Agelaioides badius & 0.07 & 0.13 & - & 0.07 & - & - \\
\hline Screaming Cowbird & Molothrus rufoaxillaris & - & 0.07 & - & - & - & - \\
\hline Shiny Cowbird & Molothrus bonariensis & - & 0.40 & - & 0.20 & 0.20 & 0.13 \\
\hline Long-tailed Meadowlark & Leistes loyca & 0.07 & - & - & - & - & - \\
\hline White-browed Blackbird & Leistes superciliaris & - & - & - & 0.20 & - & - \\
\hline European Greenfinch & Chloris chloris & - & 0.07 & 0.07 & - & 0.13 & - \\
\hline European Goldfinch & Carduelis carduelis & - & - & - & - & - & 0.07 \\
\hline Hooded Siskin & Spinus magellanica & 0.07 & 0.20 & - & - & - & - \\
\hline House Sparrow & Passer domesticus & 0.27 & 0.87 & 0.93 & 0.40 & 0.80 & 1.00 \\
\hline Crested Myna & Acridotheres cristatellus & - & - & - & - & 0.07 & - \\
\hline
\end{tabular}

Species names in bold indicate exotic species.

Bird species richness decreased with increasing sample coverage of each transect, showing that those transects with the highest species richness values had the lowest estimated sampling completeness. Therefore, this relationship suggests that transects with the highest species richness were undersampled, and some species were not detected. In spite of this, consistent changes in species richness between habitats were found.

Bird species richness was the highest in suburban areas, and this pattern may be related to a higher habitat complexity and more resources in suburban areas compared to urban and rural ones (Guthrie 1974, Vale and Vale 1976, Blair 1996, Leveau 2019). On the other hand, urban areas were dominated by a few exotic species that nest in buildings and have an omnivorous diet, such as the House Sparrow and the Rock Dove, and this pattern has been documented by several authors worldwide (Blair 1996; Clergeau et al. 1998; Conole and Kirkpatrick 2011; van Rensburg et al. 2009; Silva et al. 2016; Escobar-Ibáñez et al. 2020).

Table 2 Final generalized linear mixed models showing the relationship between different bird diversity facets and habitat types, years, and sample coverage along rural-urban gradients in central Argentina

\begin{tabular}{|c|c|c|c|c|c|}
\hline Response variable & Predictor & Estimate & Standard error & $z / t$ value & $P$ \\
\hline \multirow[t]{4}{*}{ Bird species richness } & Intercept & 2.156 & 0.200 & 10.773 & $<0.001$ \\
\hline & Suburban & 0.434 & 0.102 & 4.244 & $<0.001$ \\
\hline & Urban & -0.151 & 0.129 & -1.169 & 0.242 \\
\hline & Sample coverage & -0.638 & 0.256 & -2.492 & 0.013 \\
\hline \multirow[t]{4}{*}{ SES functional diversity } & Intercept & -0.612 & 0.294 & -2.080 & 0.041 \\
\hline & Suburban & -0.388 & 0.219 & -1.774 & 0.080 \\
\hline & Urban & -0.614 & 0.220 & -2.789 & 0.007 \\
\hline & Year (2017) & 0.393 & 0.178 & 2.206 & 0.030 \\
\hline \multirow[t]{4}{*}{ SES phylogenetic diversity } & Intercept & 0.180 & 0.459 & 0.392 & 0.696 \\
\hline & Suburban & 0.530 & 0.206 & 2.572 & 0.012 \\
\hline & Urban & 0.893 & 0.232 & 3.846 & $<0.001$ \\
\hline & Sample coverage & -1.308 & 0.582 & -2.247 & 0.027 \\
\hline
\end{tabular}


(a)

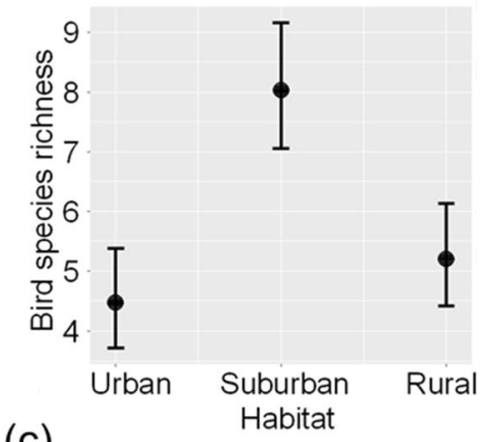

(c)
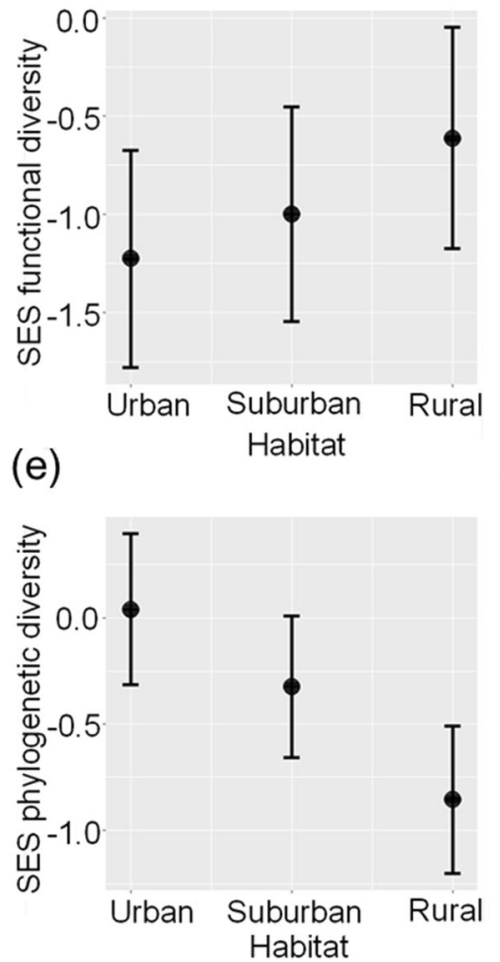

(b)

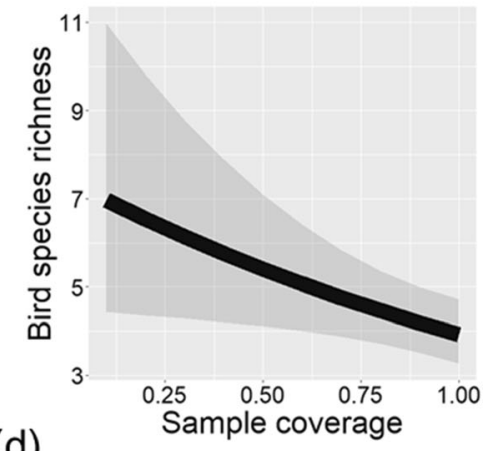

(d)

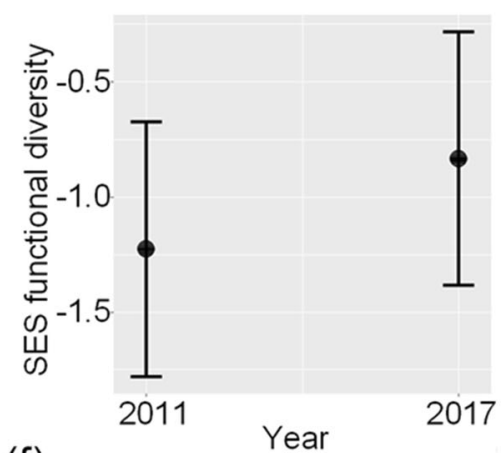

(f)

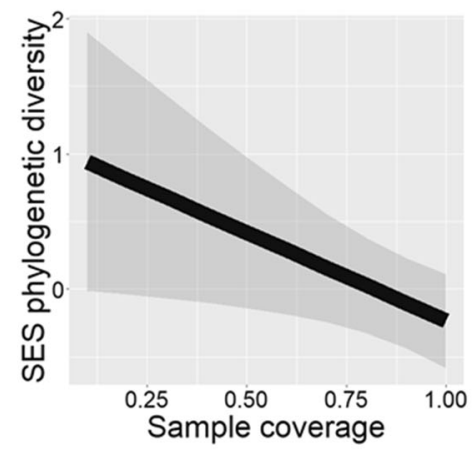

Fig. 2 Bird species richness variation between $\mathbf{a}$ habitat types and $\mathbf{b}$ in relation to sample coverage; SES of functional diversity variation between $\mathbf{c}$ habitat types and $\mathbf{d}$ years; and SES of phylogenetic diversity variation between $\mathbf{e}$ habitat types and $\mathbf{f}$ in relation to sample coverage along ruralurban gradients in central Argentina. SES, standardized effect size; values higher than zero indicate a greater diversity than expected by the null model, whereas values lower than zero indicate lower diversity than expected by the null model. Points are means, and vertical lines and grey areas are confident intervals

The SES of functional diversity was the lowest in urban areas showing functional clustering. This suggested that urban bird assemblages were molded by environmental filtering, allowing the permanence of bird species with certain functional traits, such as omnivorous diet and resident status. This result agrees with those found by other authors at local scales in the USA (Evans et al., 2018), Germany (Schütz and Schulze 2015), South Africa (Weideman et al. 2020), but see MorenoContreras et al. (2019) in Mexico. However, studies conducted at larger spatial scales found the opposite pattern
(Oliveira Hagen et al. 2017), suggesting that urban areas can provide a variety of resources for birds, increasing their functional diversity. The contrasting patterns found between studies suggest that the relationship between functional diversity and urbanization varies with the spatial scale that is considered in each study.

The SES of functional diversity was higher in 2017 than in 2011, showing a pattern of functional clustering in 2011 and randomness in 2017. This pattern could be related to more favorable climatic conditions in 2017. This year was warmer and wetter than 2011, possibly 


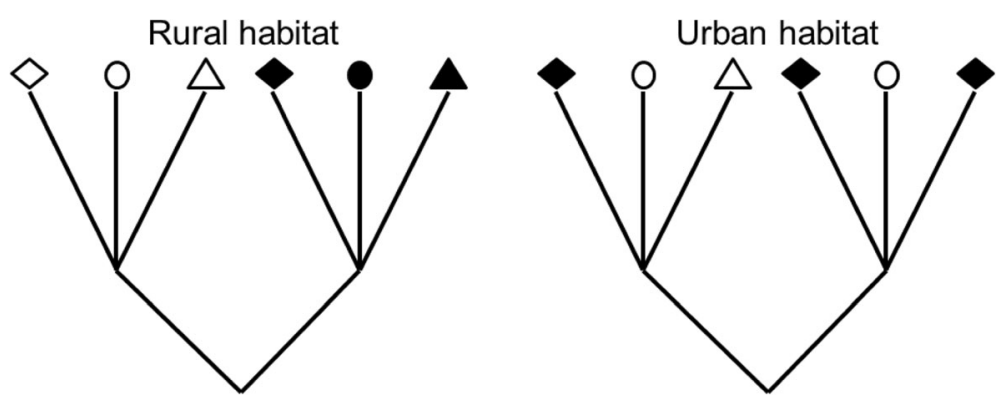

Fig. 3 Summary of the results obtained in the study. Species inhabiting rural areas (black symbols) are phylogenetically clustered, and they are functionally diverse (different symbols). On the other hand, species inhabiting urban areas (black symbols) belong to different clades but have similar traits (same symbols)

resulting in higher food availability for birds (Weyland et al. 2019). In addition, rural areas had a replacement of crops by abandoned fields in 2017, which probably resulted in increased habitat heterogeneity and resources availability for birds (Orłowski 2005, Herzon et al. 2014). These interannual increases in resources and habitat heterogeneity probably allowed a change from functional clustering to functional randomness where the variety of traits is proportional to the observed species richness.

On the other hand, the increase in functional diversity between years may be related to the colonization by species that are functionally different to the other coexisting species. For example, the Barn Swallow (Hirundo rustica) is a migrant species that typically breeds in North America during the boreal summer and migrates to winter in South America. However, this species started to breed in the coast of central Argentina in the early 1980s, and currently, it is expanding its breeding range (Martínez, 1983, Idoeta et al. 2011, Segura 2017). In this study, the species was recorded in rural areas during 2011, whereas it was recorded in the three habitats during 2017. According to Wilman et al. (2014) and Brown and Brown (2020), the Barn Swallow feeds on aerial invertebrates which contrasts with the dominant functional types in urban and suburban areas, comprised mainly of groundfeeding and omnivorous (Leveau 2013).

The SES of phylogenetic diversity was lower than random in rural habitats, which suggests that bird species adaptation to rural areas is phylogenetically preserved. Rural areas were particularly inhabited by seed-eater species of the Emberizidae family, such as Grassland Yellow-finch (Sicalis luteola), the Doublecollared Seedeater (Sporophila caerulescens), and the Rufous-collared Sparrow (Zonotrichia capensis), and also by migratory and insectivorous species of the Tyrannidae family, such as the Tropical Kingbird (Tyrannus melancholicus) and the Fork-tailed Flycatcher (Tyrannus savana) (Table 1). This pattern agrees with those obtained by Weideman et al. (2020), who found more clustered phylogenetic structures in rural than urban areas. However, Moreno-Contreras et al. (2019) found a random phylogenetic structure in rural and urban green habitats. Differences between studies may be related to differences in the species pools and the habitats compared. For example, Moreno-Contreras et al. (2019) compared bird communities in urban green areas with agricultural and natural areas of the Chihuahuan Desert.

\section{Conclusions}

Bird communities in rural areas tended to be phylogenetically clustered and functionally random, suggesting that phylogenetic history influenced species presence in rural areas (Fig. 3). In contrast, bird communities in urban areas tended to be phylogenetically random and functionally clustered, evidencing environmental filtering. Moreover, due to species with similar traits but belonging to different clades, a possible process of functional convergence was related to urbanization (Fig. 3) (Webb et al. 2002). Along the rural-urban gradients analyzed, there was a significant increase of bird functional diversity after a 6-year gap in data collection, probably related to increases in precipitation and temperature between years. However, the processes structuring bird communities probably were stable in the long term. Multiscale studies are needed to get insights into bird community assembly rules of urban areas.

\section{Abbreviations \\ GLMM: Generalized linear mixed models; LRT: Likelihood ratio test; SES: Standardized effect size}

\section{Supplementary Information}

The online version contains supplementary material available at https://doi. org/10.1186/s13717-021-00302-8.

Additional file 1: Table S1. Functional traits for the species recorded during December 2011 and 2017 along three urban-rural gradients of central Argentina. Clutch: mean clutch size; Inv: invertebrates; Vend: mammals and birds; Vect: reptiles, snakes, amphibians, salamanders; Vfish: fish; 
Vunk: vertebrates-general or unknown; Scav: scavenge, garbage, offal, carcasses, trawlers, carrion; Nect: nectar; PlantO: plant material; Watbelowsurf: foraging below the water surfaces; Wataroundsurf: foraging on or just $(<5$ inches) below water surface; Understory: Foraging below $2 \mathrm{~m}$ in understory in forest, forest edges, bushes or shrubs; Midhigh: Foraging in mid to high levels in trees or high bushes ( $2 \mathrm{~m}$ upward), but below canopy

\section{Acknowledgements}

I thank three anonymous reviewers for constructive revisions that improved a first version of the manuscript. Paloma Garcia Orza improved the English writing.

\section{Author's contributions}

Conceptualization: L.M.L. Data collection and analysis: L.M.L. Writing—original draft preparation: L.M.L. Writing—review and editing: L.M.L. Supervision: L.M.L. Funding acquisition: L.M.L. The author has read and agreed to the published final version of the manuscript

\section{Funding}

This study was partially funded by Project PICT-2015-0978 of the Agencia Nacional de Promoción de la Investigación, el Desarrollo Tecnológico y la Innovación.

\section{Availability of data and materials}

Data is available upon author request

\section{Declarations}

Ethics approval and consent to participate

Not applicable

\section{Consent for publication}

Not applicable

\section{Competing interests}

The author declares that he has no competing interests.

Received: 22 January 2021 Accepted: 21 April 2021

\section{Published online: 27 May 2021}

\section{References}

Argañaraz JP, Pizarro GG, Zak M, Landi MA, Bellis LM (2015) Human and biophysical drivers of fires in Semiarid Chaco mountains of Central Argentina. Sci Total Environ 520:1-12. https://doi.org/10.1016/j.scitotenv.2015.02.081

Aronson MF, La Sorte FA, Nilon CH, Katti M, Goddard MA, Lepczyk CA et al (2014) A global analysis of the impacts of urbanization on bird and plant diversity reveals key anthropogenic drivers. Proceed Royal Soc B 281(1780):20133330

Bates D, Maechler M, Bolker B, Walker S, Christensen RHB, Singmann $\mathrm{H}$ et al (2018) Package 'Ime4'. Version 1:17

Beninde J, Veith M, Hochkirch A (2015) Biodiversity in cities needs space: a metaanalysis of factors determining intra-urban biodiversity variation. Ecol Lett 18(6):581-592. https://doi.org/10.1111/ele.12427

Blair RB (1996) Land use and avian species diversity along an urban gradient. Eco Appl 6(2):506-519. https://doi.org/10.2307/2269387

Brown MB, Brown CR (2020) Barn Swallow (Hirundo rustica), version 1.0. In: Birds of the world (P. G. Rodewald, Editor). Cornell Lab of Ornithology, Ithaca. https://doi.org/10.2173/bow.barswa.01

Cadotte MW, Tucker CM (2018) Difficult decisions: strategies for conservation prioritization when taxonomic, phylogenetic and functional diversity are not spatially congruent. Biol Conserv 225:128-133. https://doi.org/10.1016/j. biocon.2018.06.014

Clergeau P, Savard JPL, Mennechez G, Falardeau G (1998) Bird abundance and diversity along an urban-rural gradient: a comparative study between two cities on different continents. The Condor 100(3):413-425. https://doi.org/1 $0.2307 / 1369707$

Conole LE, Kirkpatrick JB (2011) Functional and spatial differentiation of urban bird assemblages at the landscape scale. Landscape Urban Plan 100(1-2):1123. https://doi.org/10.1016/j.landurbplan.2010.11.007

Devictor V, Mouillot D, Meynard C, Jiguet F, Thuiller W, Mouquet N (2010) Spatial mismatch and congruence between taxonomic, phylogenetic and functional diversity: the need for integrative conservation strategies in a changing world. Ecol Lett 13(8):1030-1040. https://doi.org/10.1111/j.1461-0248.2010.014 93.x

Díaz S, Cabido M (2001) Vive la difference: plant functional diversity matters to ecosystem processes. Trends Ecol Evol 16(11):646-655. https://doi.org/10.101 6/S0169-5347(01)02283-2

Emerson BC, Gillespie RG (2008) Phylogenetic analysis of community assembly and structure over space and time. Trends Ecol Evol 23(11):619-630. https:// doi.org/10.1016/j.tree.2008.07.005

Ericson PGP, Zuccon D, Ohlson Jl, Johansson US, Alvarenga H, Prum RO (2006) Higher-level phylogeny and morphological evolution of tyrant flycatchers, cotingas, manakins, and their allies (Aves: Tyrannida). Mol Phylogenet Evol 40(2):471-483. https://doi.org/10.1016/j.ympev.2006.03.031

Escobar-lbáñez JF, Rueda-Hernández R, MacGregor-Fors I (2020) The greener the better! Avian communities across a neotropical gradient of urbanization density. Front Ecol Evol 8:285

Evans BS, Reitsma R, Hurlbert AH, Marra PP (2018) Environmental filtering of avian communities along a rural-to-urban gradient in Greater Washington, DC, USA. Ecosphere 9(11):e02402. https://doi.org/10.1002/ecs2.2402

Fox J, Weisberg S, Adler D, Bates D, Baud-Bovy G, Ellison S et al (2012) Package 'car'. R Foundation for Statistical Computing, Vienna

Grimm NB, Faeth SH, Golubiewski NE, Redman CL, Wu J, Bai X, Briggs JM (2008) Global change and the ecology of cities. Science 319(5864):756-760. https:// doi.org/10.1126/science.1150195

Guthrie DA (1974) Suburban bird populations in southern California. Am Midl Nat 92(2):461-466. https://doi.org/10.2307/2424310

Herzon I, Marja R, Menshikova S, Kondratyev A (2014) Farmland bird communities in an agricultural landscape in Northwest Russia: seasonal and spatial patterns. Agric Ecosyst Environ 183:78-85. https://doi.org/10.1016/j.agee.2 013.10 .015

Hothorn T, Bretz F, Westfall P, Heiberger RM, Schuetzenmeister A, Scheibe S, Hothorn MT (2016) Package 'multcomp'. Simultaneous inference in general parametric models. Project for Statistical Computing, Vienna

Hsieh TC, Ma KH, Chao A (2016) iNEXT: an R package for rarefaction and extrapolation of species diversity (Hill numbers). Methods Ecol Evol 7(12): 1451-1456. https://doi.org/10.1111/2041-210X.12613

Ibáñez-Álamo JD, Rubio E, Benedetti Y, Morelli F (2017) Global loss of avian evolutionary uniqueness in urban areas. Glob Change Biol 23(8):2990-2998. https://doi.org/10.1111/gcb.13567

Idoeta FM, Roda MA, Roesler CI (2011) La Golondrina Tijerita Hirundo rustica sigue expandiendo su área de nidificación en Argentina. Cotinga 33:58-60

James G, Witten D, Hastie T, Tibshirani R (2013) An introduction to statistical learning: with applications in R. Springer, New York

Jetz W, Thomas GH, Joy JB, Redding DW, Hartmann K, Mooers AO (2014) Global distribution and conservation of evolutionary distinctness in birds. Curr Biol 24(9):919-930. https://doi.org/10.1016/j.cub.2014.03.011

Kembel SW, Cowan PD, Helmus MR, Cornwell WK, Morlon H, Ackerly DD, Blomberg SP, Webb CO (2010) Picante: R tools for integrating phylogenies and ecology. Bioinformatics 26(11):1463-1464. https://doi.org/10.1093/ bioinformatics/btq166

Kingfield DM, De Beurs KM (2017) Landsat identification of tornado damage by land cover and an evaluation of damage recovery in forests. J Appl Meteorol Climatol 56(4):965-987. https://doi.org/10.1175/JAMC-D-16-0228.1

La Sorte FA, Lepczyk CA, Aronson MF, Goddard MA, Hedblom M, Katti M et al (2018) The phylogenetic and functional diversity of regional breeding bird assemblages is reduced and constricted through urbanization. Divers Distribut 24(7):928-938. https://doi.org/10.1111/ddi.12738

Laliberté E, Legendre P, Shipley B, Laliberté ME (2014) FD: measuring functional diversity from multiple traits, and other tools for functional ecology. $R$. package ver. 1.0-11

Leong M, Roderick GK (2015) Remote sensing captures varying temporal patterns of vegetation between human-altered and natural landscapes. PeerJ 3:e1141. https://doi.org/10.7717/peerj.1141

Lepczyk CA, Mertig AG, Liu J (2004) Assessing landowner activities related to birds across rural-to-urban landscapes. Environ Manag 33(1):110-125. https:// doi.org/10.1007/s00267-003-0036-z

Leveau LM (2013) Bird traits in urban-rural gradients: how many functional groups are there? J Ornithol 154(3):655-662. https://doi.org/10.1007/s10336012-0928-x 
Leveau LM (2018) Urbanization, environmental stabilization and temporal persistence of bird species: a view from Latin America. PeerJ 6:e6056. https:// doi.org/10.7717/peerj.6056

Leveau LM (2019) Primary productivity and habitat diversity predict bird species richness and composition along urban-rural gradients of central Argentina. Urban For Urban Green 43:126349. https://doi.org/10.1016/j.ufug.2019.05.011

Leveau LM, Isla FI, Bellocq MI (2015) Urbanization and the temporal homogenization of bird communities: a case study in central Argentina. Urban Ecosyst 18(4):1461-1476. https://doi.org/10.1007/s11252-015-0469-1

Leveau LM, Leveau CM (2020) Street design in suburban areas and its impact on bird communities: considering different diversity facets over the year. Urban Forest Urban Greening 48:126578. https://doi.org/10.1016/j.ufug.2019.126578

Li SP, Cadotte MW, Meiners SJ, Hua ZS, Jiang L, Shu WS (2015) Species colonisation, not competitive exclusion, drives community overdispersion over long-term succession. Ecol Lett 18(9):964-973. https://doi.org/10.1111/ ele.12476

Liu J, Bai H, Ma H, Feng G (2019) Bird diversity in Chinese urban parks was more associated with natural factors than anthropogenic factors. Urban For Urban Green 43:126358. https://doi.org/10.1016/j.ufug.2019.06.001

Lüdecke D, Bartel A, Schwemmer C, Powell C, Djalovski A (2018) Package 'sjPlot': Data visualization for statistics in social science. $R$ package version 2.4. 1. The Comprehensive R Archive Network. https://CRAN.R-project.org/package= sjplot.

Magura T, Lövei GL, Tóthmérész B (2018) Conversion from environmental filtering to randomness as assembly rule of ground beetle assemblages along an urbanization gradient. Sci Rep 8:16992

Martínez MM (1983) Nidificación de Hirundo rustica erythrogaster (Boddaert) en la Argentina (Aves, Hirundinidae). Neotropica 29(81):83-86

Morelli F, Benedetti Y, Su T, Zhou B, Moravec D, Šímová P, Liang W (2017) Taxonomic diversity, functional diversity and evolutionary uniqueness in bird communities of Beijing's urban parks: effects of land use and vegetation structure. Urban For Urban Green 23:84-92. https://doi.org/10.1016/j.ufug.2017.03.009

Moreno-Contreras I, de Silva HG, Andrade-González V, Vital-García C, OrtizRamírez MF (2019) Disentangling an avian assemblages' evolutionary and functional history in a Chihuahuan desert city. Urban Ecosyst 22(5):893-906. https://doi.org/10.1007/s11252-019-00864-8

Oliveira Hagen E, Hagen O, Ibáñez-Álamo JD, Petchey OL, Evans KL (2017) Impacts of urban areas and their characteristics on avian functional diversity. Front Ecol Evol 5:84. https://doi.org/10.3389/fevo.2017.00084

Orłowski G (2005) Endangered and declining bird species of abandoned farmland in south-western Poland. Agric Ecosyst Environ 111(1-4):231-236. https://doi.org/10.1016/j.agee.2005.06.012

Palacio FX (2020) Urban exploiters have broader dietary niches than urban avoiders. Ibis 162(1):42-49. https://doi.org/10.1111/ibi.12732

Paradis E, Claude J, Strimmer K (2004) APE: analyses of phylogenetics and evolution in R language. Bioinformatics 20(2):289-290. https://doi.org/10.1 093/bioinformatics/btg412

Petchey OL, Evans KL, Fishburn IS, Gaston KJ (2007) Low functional diversity and no redundancy in British avian assemblages. J Anim Ecol 76(5):977-985. https://doi.org/10.1111/j.1365-2656.2007.01271.x

Petchey OL, Gaston KJ (2002) Functional diversity (FD), species richness and community composition. Ecol Lett 5(3):402-411. https://doi.org/10.1046/j.14 61-0248.2002.00339.x

Pickens BA, Marcus JF, Carpenter JP, Anderson S, Taillie PJ, Collazo JA (2017) The effect of urban growth on landscape-scale restoration for a fire-dependent songbird. J Environ Manag 191:105-115. https://doi.org/10.1016/j.jenvman.2 017.01 .005

Pinheiro J, Bates D, DebRoy S, Sarkar D, Team RC (2013) nlme: linear and nonlinear mixed effects models. R Pack Version 3(1):111

R Core Team (2017) R: a language and environment for statistical computing (version 3.4.0). Vienna: R Foundation for Statistical Computing

Rajashekara S, Venkatesha MG (2015) Temporal and spatial avian community composition in urban landscapes of the Bengaluru region, India. J Environ Biol 36(3):607

Rambaut A, Drummond AJ (2002-2015) TreeAnnotator v 1.8.2. https://beast.bio ed.ac.uk/. Accessed 25 Oct 2018

Rota C, Manzano P, Carmona CP, Malo JE, Peco B (2017) Plant community assembly in Mediterranean grasslands: understanding the interplay between grazing and spatio-temporal water availability. J Veget Sci 28(1):149-159. https://doi.org/10.1111/jvs.12470
Schütz C, Schulze CH (2015) Functional diversity of urban bird communities: effects of landscape composition, green space area and vegetation cover. Ecol Evol 5(22):5230-5239. https://doi.org/10.1002/ece3.1778

Segura LN (2017) Southward breeding range expansion in Argentina and first breeding record of Barn Swallow Hirundo rustica in Patagonia. Cotinga 39: $60-62$

Shanahan DF, Strohbach MW, Warren PS, Fuller RA (2014) The challenges of urban living. In: Gil D, Brumm H (eds) Avian urban ecology behavioural and physiological adaptations. Oxford University Press, Oxford, pp 3-20

Shochat E, Stefanov WL, Whitehouse MEA, Faeth SH (2004) Urbanization and spider diversity:influences of human modification of habitat structure and productivity. Ecol Appl 14(1):268-280.

Shochat E, Warren PS, Faeth SH, McIntyre NE, Hope D (2006) From patterns to emerging processes in mechanistic urban ecology. Trends Ecol Evol 21(4): 186-191. https://doi.org/10.1016/j.tree.2005.11.019

Silva CP, Sepúlveda RD, Barbosa O (2016) Nonrandom filtering effect on birds: species and guilds response to urbanization. Ecol Evol 6(11):3711-3720. https://doi.org/10.1002/ece3.2144

Sol D, Bartomeus I, González-Lagos C, Pavoine S (2017) Urbanisation and the loss of phylogenetic diversity in birds. Ecol Lett 20(6):721-729. https://doi.org/1 $0.1111 /$ ele. 12769

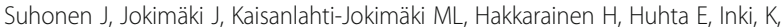
Suorsa P (2009) Urbanization and stability of a bird community in winter. Ecoscience 16(4):502-507.

Swenson NG (2014) Functional and phylogenetic ecology in R (pp. 64-75). New York: Springer, https://doi.org/10.1007/978-1-4614-9542-0

Vale TR, Vale GR (1976) Suburban bird populations in west-central California. J Biogeogr p. 157-165.

van Rensburg BJ, Peacock DS, Robertson MP (2009) Biotic homogenization and alien bird species along an urban gradient in South Africa. Landscape Urban Plan 92(3-4):233-241. https://doi.org/10.1016/j.landurbplan.2009.05.002

Webb CO, Ackerly DD, McPeek MA, Donoghue MJ (2002) Phylogenies and community ecology. Ann Rev Ecol Syst 33(1):475-505. https://doi.org/10.114 6/annurev.ecolsys.33.010802.150448

Weideman EA, Slingsby JA, Thomson RL, Coetzee BT (2020) Land cover change homogenizes functional and phylogenetic diversity within and among African savanna bird assemblages. Landscape Ecol 35(1):145-157. https://doi. org/10.1007/s10980-019-00939-z

Weyland F, Baudry J, Ghersa C (2019) Short-term effects of a severe drought on avian diversity and abundance in a Pampas Agroecosystem. Austral Ecol 44(8):1340-1350. https://doi.org/10.1111/aec.12808

Wilman H, Belmaker J, Simpson J, de la Rosa C, Rivadeneira MM, Jetz W (2014) EltonTraits 1.0: species-level foraging attributes of the world's birds and mammals (Ecological Archives E095-178). Ecology 95(7):2027-2027. https:// doi.org/10.1890/13-1917.1

\section{Publisher's Note}

Springer Nature remains neutral with regard to jurisdictional claims in published maps and institutional affiliations.

\section{Submit your manuscript to a SpringerOpen ${ }^{\circ}$ journal and benefit from:}

- Convenient online submission

- Rigorous peer review

- Open access: articles freely available online

- High visibility within the field

- Retaining the copyright to your article

Submit your next manuscript at $>$ springeropen.com 